Jurnal Kesehatan Masyarakat

\title{
Risk Factors and Early Symptoms Related to Respiratory Disease in Pedicab Drivers in Surabaya
}

\author{
Amelia Lorensia ${ }^{1 凶}$, Rivan Virlando Suryadinata ${ }^{2}$ I Nyoman Yoga Diputra ${ }^{1}$ \\ ${ }^{1}$ Faculty of Pharmacy, University of Surabaya \\ ${ }^{2}$ Faculty of Medicine, University of Surabaya
}

\begin{tabular}{l} 
Article Info \\
\hline Article History: \\
Submitted May 2019 \\
Accepted October 2019 \\
Published November 2019 \\
\hline Keywords: \\
respiratory disease, pedicab \\
drivers, risk factor of COPD, \\
early symptom of COPD. \\
\hline DOI \\
https://doi.org/10.15294/ \\
kemas.v15i2.19255
\end{tabular}

\begin{abstract}
Various factors which cause respiratory diseases such as smoking, air pollution, and disease history are found in pedicab. The purpose of this study was to understand the risk factors and early symptoms that related to respiratory disease in pedicab drivers. This study used observational cross-sectional design with purposive sampling. Variables that were recorded in this study were lung function risk factors and early symptoms of respiratory disorders. The number of samples was 148 respondents (135 with respiratory disorder and 13 without respiratory disorder). The results of this study found the most common risk factor was air pollution exposure. In 145 respondents (97.97\%), the average lung function was $52.56 \%$. The most frequent early symptom was dyspnea with percentage of $7.43 \%$ and average lung function value of $26.20 \%$. Air pollution was the most common risk factor and dyspnea was the most common early symptom in pedicab drivers with respiratory disorders in Surabaya.
\end{abstract}

\section{Introduction}

Lung is internal organ that is most vulnerable to infection and injury from outside environment due to constant exposure of particles, chemicals and infectious organisms in the air. Respiratory disorders can cause disability and death in all groups of people all over the world. Environmental exposure and poverty can increase the vulnerability to this disease. Respiratory diseases are the top 5 causes of death worldwide (Forum of International Respiratory Societies, 2017). The most common source of environmental exposure in the form of air pollution is coming from transportation vehicles, which produces around $70 \%$ of total air pollution (Boediningsih, 2011).

Emissions from transportation also have high levels of air pollution in urban areas of developing countries such as Indonesia, therefore many large cities experience problems with high levels of air pollution
(Jiang et al., 2016). Transportation is a significant contributor of air pollution. Land transportation is estimated to be responsible for up to $30 \%$ of particulate emissions in European cities and up to $50 \%$ in developing countries, mostly due to diesel vehicles. However, the total contribution of transportation as particle contributor to air pollution can vary greatly from $12 \%$ to $70 \%$ of the total pollutants (Forum of International Respiratory Societies, 2017). In 2013, transportation accounted for more than half of carbon monoxide and nitrogen monoxide emission and nearly a quarter of hydrocarbons in the air (Union of Concerned Scientists, 2019).

Indonesia is a developing country and is still in the stage of development in every city, including Surabaya as one of the big city in Indonesia. Outside air pollution describes the magnitude of the risks to health, especially related to the triggers of acute

\footnotetext{
Correspondence Address:

Faculty of Pharmacy, University of Surabaya, Jl. Raya Kalirungkut, 60293 Indonesia

Email: amelia.lorensia@gmail.com
} 
respiratory symptoms and exacerbation of respiratory disease. Air pollution can stimulate pathophysiological changes that characterize COPD (Chronic Obstructive Pulmonary Disease) (Hu et al., 2015). Air pollution produces various respiratory diseases such as COPD which is a chronic lung disease characterized by disruption of airflow in the airways that is not fully reversible. These airflow barriers are progressive and are associated with lung inflammatory responses to toxic or dangerous particles or gases (GOLD, 2019). Systematic review and meta-analysis confirm that short-term exposure to air pollution can significantly pose a risk of COPD exacerbation (Li et al., 2016).

Air pollution from motorized vehicle emissions is a serious health hazard with significant impact on the health of people who spend lot of time on the highway such as driver (Zhang, Batterman, 2014). Other research shows that pedicab drivers work more than 8 hours per day on the road (Farooque, Jayacandra, 2014), which causes them to be exposed to air pollution and chemicals such as ozone, nitrogen, hydrocarbons (Kelly, 2014), therefore there is a high risk of lung damage. Outdoor air pollution significantly triggers acute exacerbation of COPD which causes an increase in symptoms, hospital emergency visits, and risk of death (Ko, Hui, 2012).

Risk factors of smoking are one of the causes of COPD that have a very significant effect on the disease (PDPI, 2011). Kirkorowicz et al., (2013) reported that smoking is a social habit of pedicab drivers. A study in Medan city by Alamsyah et al., (2012) showed that out of 115 samples of pedicab drivers, $60.9 \%$ was smokers. Smoking habits also proved to have a negative effect on Body Mass Index (BMI) (Jitnarin et al., 2016; Wang et al., 2016). Nonideal BMI is a sign of a nutritional disorder, while the condition of malnourished people generally comes from the middle to lower economy as in the profession of pedicab drivers (Silalahio et al., 2016). Pedicab drivers who have an average income of Rp. 30,000 to Rp. 50,000 per day (Mangatta, 2016), included in the low-income profession. Lack of nutritional intake can cause interference with immunity, so there is a high risk of lung infection (Hamer et al., 2009).

The research by Hajat et al., (2015) found that there was a relationship between low socioeconomic level and exposure to air pollution and hazardous particles with high concentrations that could potentially cause chronic lung disease. Severe pulmonary function disorders such as COPD can significantly become a burden for a person at working age economically and socially. Therefore, further efforts are needed to improve the diagnosis of COPD and management of therapy for maximum results (Fletcher, 2011). Identification of risk factors is needed to prevent more serious illness or even death, because COPD is the 3rd largest cause of death. Identification of risk factors such as exposure to air pollution in workplace, tobacco smoking, social status, viral infection, age and sex are important steps in prevention and management of respiratory disease (PDPI, 2011).

Frequent exacerbations in COPD is a major responsibility of the health care system because the main effects can reduce quality of life related to health, accelerate the decline in lung function, and increase mortality in individual patients. Early prevention with proper health care is the patient's first action to prevent exacerbations. Therefore, it is necessary to recognize the risk factors and initial symptoms of COPD (Yawn, 2013). The purpose of this study was to determine the effect of risk factors and the initial symptoms which a person has on lung function disorders in pedicab drivers in Surabaya.

\section{Method}

This study is an observational study using a cross sectional design to determine the correlation between risk factors of chronic obstructive pulmonary disease that occurs in pedicab drivers. Pedicab is form of public vehicle which is non-motorized, has a tricycle, a lid (the lid can be opened), a saddle in the back, a seat for passengers, and is running by human power.

The variables used in the study can be classified into independent variables, namely variables that explain and influence other variables, such as lung function (FEV1 / FVC), and dependent variables, namely the variables that are explained and influenced by 
the independent variables. In this study, the dependent variables were COPD risk factors and early symptoms of COPD. Lung function is the ability of the lungs to enter air and expel air from the lungs. In this study, a person was said to experience respiratory disorders if the measurement value of FEV1/FVC was less than $70 \%$ and they were said to have no pulmonary function disorder if the FEV1/FVC value is above 70\% (GOLD, 2019). The risk factors for COPD in this study consisted of: air pollution, age, history of illness, and obesity. Early symptoms of COPD include: chronic cough, wheezing, tightness, limited physical activity, and feeling of heaviness in the chest.

The population is all pedicab driver in the East Surabaya area. The sample (respondent) used in this study was pedicab drivers in the Surabaya area who met the inclusion and exclusion criteria. Inclusion criteria include: (1) Male sex; (2) Age 18-60 years; (3) Active smokers; (4) Has become a pedicab driver for approximately 5 years (Kelly, 2014); (5)Did not having respiratory disease or disorder other than COPD which is known from the patient's admission; and (6) Patients do not have mental disorders/disabilities.

The sampling technique used is random sampling (non-probability sampling) with purposive sampling method. The sample size used in this study was at least 70 people. Sample calculation method, using a formula whose population is known. Population size is known from research on pedicab transportation policy in Surabaya City in 2016 (Indari, 2016). This study mentions the provisions of pedicabs operated during the day amounting to $2 / 3$ of the number of existing pedicabs which is 400 , so that the population is $2 / 3$ times 400 (the number of pedicab drivers in Surabaya), namely 266.

The formula for sample size was:

with $\mathrm{N}=266 ; \mathrm{p}=\mathrm{q}=$ proportion of variables $(0.5) ; \mathrm{d}^{2}=$ degree of deviation from the desired population $(0.1) ; Z=1.96$. From the above formula, the minimum sample size of 70 was required.

Data collection consisted of initial preparation of the questionnaire which was carried out by quoting several articles/journals/ guidelines such as Walker et al., (2019), GOLD (2019), and Peng et al. (2019). Then the validity and reliability of the questionnaire were examined. Afterwards, preliminary study was conducted. The acquired respondents were given informed consent, and then measurement of BMI and lung function with a spirometer were conducted. The data were analyzed using descriptive analysis because the number of respondents from the two groups were not the same, consequently the correlation test or difference of mean test could not be carried out.

\section{Results and Discussion}

In total, there were 153 pedicab drivers who approved to be included in the interview process regarding lung function disorders. However, only 148 pedicab drivers were analyzed because 3 data were incomplete due to loss of data during interview process, 1 pedicab driver did not want to undergo spirometer test, and 1 pedicab driver had a history of lung disease. The study was conducted from March to December 2018 using observational cross sectional design with purposive sampling method. Sampling sites were chosen from 4 locations. The location and number of respondents obtained are presented in table 1.

Respondents in this study were

Table 1. Distribution of Research Sample Collection

\begin{tabular}{lll}
\hline No. & Sampling Sites & Number of respondents \\
\hline 1 & Wonokromo Station; Jl. Wonokromo, Jagir. & 93 \\
2 & Soetomo Hospital; Jl. Mayjend Prof. Dr. Moestopo & 27 \\
3 & Rungkut Baru Market; Jl. Rungkut Alang-alang & 15 \\
4 & Bratang Jaya Terminal; Jl. Manyar & 19 \\
\hline
\end{tabular}

The questionnaire could be declared valid if the calculated $r_{\text {value }}$ obtained from the SPSS version 24.0 program was greater than 0.361 (Table 2). The questionnaires could be considered reliable if the alpha chronbach value was $>0.60$. The chronbach alpha results obtained was 0.613 , so the questionnaire was declared reliable. 
Table 2. Results of Validation of COPD Risk Factor and COPD Early Symptoms Questionnaires

\begin{tabular}{llllll}
\hline Questionnaire & No. & Question Item & $\mathrm{r}_{\text {value }}$ & $\mathrm{r}_{\text {table }}$ & Conclusions \\
\hline COPD Risk Factor & 1 & Smoke & 0,665 & 0,361 & valid \\
& 2 & Air pollution & 0,544 & 0,361 & valid \\
& 3 & Age & 0,592 & 0,361 & valid \\
& 4 & Obesity & 0,469 & 0,361 & valid \\
& 5 & History of the disease & 0,664 & 0,361 & Valid \\
\hline COPD Early & 1 & Chronic cough & 0,408 & 0,361 & valid \\
Symptoms & 2 & Breathless & 0,499 & 0,361 & valid \\
& 3 & Wheezing & 0,364 & 0,361 & valid \\
& 4 & Chest tightness & 0,390 & 0,361 & valid \\
& 5 & Limitation of physical activity & 0,683 & 0,361 & valid \\
\hline
\end{tabular}

Table 3. Distribution of the Characteristics of Respondents

\begin{tabular}{llllll} 
Characteristics of Respondents & \multicolumn{4}{l}{ Respondent (n:148) } \\
\hline & & $\begin{array}{l}\text { Group with Respiratory } \\
\text { Disorders (n:135) }\end{array}$ & $\begin{array}{l}\text { Group without Respiratory } \\
\text { Disorders (n:13) }\end{array}$ \\
\hline \multirow{5}{*}{ Age (years) } & Frequency & $\begin{array}{l}\text { Percentage } \\
(\%)\end{array}$ & Frequency & $\begin{array}{l}\text { Percentage } \\
(\%)\end{array}$ \\
& Early adult (18-40) & 8 & 5.88 & 2 & 15.38 \\
& Middle Adult (41-60) & 121 & 89.62 & 10 & 76.9 \\
& Late adult (>60) & 9 & 6.66 & 1 & 7.69 \\
\hline BMI (Nuttall, 2015) $\quad\left(\mathbf{K g} / \mathbf{m}^{2}\right)$ & thin & 9 & 6.66 & 1 & 7.69 \\
& normal & 81 & 60.00 & 8 & 61.53 \\
& at risk & 19 & 14.07 & 1 & 7.69 \\
& obese & 26 & 19.25 & 3 & 23.07 \\
Disease History & diabetes & 4 & 2.96 & 0 & 0 \\
& hyperuricemia & 3 & 2.22 & 0 & 0 \\
& hypertension & 4 & 2.96 & 0 & 0 \\
& dyslipidemia & 3 & 2.22 & 0 & 0 \\
& don't know & 119 & 61.48 & 13 & 100 \\
\hline
\end{tabular}

categorized by age, disease history, and body mass index (Table 3 ). The respondents were male and active smokers because from RISKESDAS 2013, in Indonesia, there were more male smokers (47.1\%) than female smokers (1.1\%). All categories were divided into two groups, namely group with respiratory disorders and group without respiratory disorders. Age category was classified based on RISKESDAS (2013). Most of the respondents were at age range of 50-54, namely $28.89 \%$ or 39 respondents in group with respiratory disorders and $30.76 \%$ or 4 respondents in group without respiratory disorders (RISKESDAS, 2013). BMI category was determined based on previous research by Nuttall (2015). Most of the respondents in both group had normal BMI (18.5-22.9). The disease history category was based on the results of direct interviews with respondents. In the group with respiratory disorders, the most common previous disease was diabetes ( 5 respondents), whereas in the group without respiratory disorders, there was no previous history of disease.

The results of measurements of pulmonary function using spirometers in 
group with respiratory disorder obtained average FEV1/FVC of $49.1 \%$ with SD 11.52 while in group without respiratory disorder, the average FEV1/FVC was $73.17 \%$ with SD 1.43. Pulmonary function testing is a tool for evaluating the respiratory system, abnormalities related to patient history, research on various pulmonary imaging and invasive tests such as bronchoscopy and open lung biopsy. Comparison between values measured in patients with normal values derived from population research can be used to determine the pathophysiology of the underlying disease. The percentage of normal predictive values can be used to assess the severity of the disease (Harahap, Aryastuti, 2012). Pulmonary function test could use 2 type of measurement equipment, namely spirometry and peak flow meter. Spirometry has more advantage compared to peak flow meter because it can measure FEV1, FVC, and PFR while peak flow meter only able to measure PFR. Therefore, spirometry is a sensitive and specific tool to measure lung function (Uyainah et al., 2014).

Based on the number of risk factors that are owned by respondents in the group with respiratory disorders, $66.66 \%$ or 90 respondents had 3 risk factors, 29.62 or 40 respondents had 4 risk factors, $2.22 \%$ or 3 respondents had 5 risk factors, and only $0.74 \%$ or 1 respondent which had 1 or 2 risk factors (Table 4). In group without respiratory disorders, $84.61 \%$ or 11 respondents had 3 risk factors, and only $7.69 \%$ or 1 respondents which had 2 or 4 risk factors.

There are 2 types of cigarettes sold in Indonesia, namely kretek (clove) cigarettes which consisted of raw materials of tobacco and clove leaves with certain flavor and aroma and white cigarette (Malson et al., 2013). In the group of respiratory disorders who had respiratory disorders, 14 respondents smoked clove cigarettes, 100 respondents smoked white cigarettes, and 21 respondents smoked both. Meanwhile, in group without respiratory disorder, 1 respondent smoked clove cigarettes, 7 respondents smoked white cigarettes, and 5 respondents smoked both (Table 4 ). The above result is in accordance with the theory which explains that kretek cigarette is more dangerous than white cigarettes because the content of nicotine and tar in clove cigarettes is higher.
Moreover, clove cigarette does not use filters so that all the results of combustion from cigarettes will be sucked in all and enter the respiratory tract (Hurt et al., 2012).

The use of tobacco in long periods of time is associated with an increased likelihood of experiencing COPD with symptoms of productive coughing and shortness of breath, and it can affect physical activity even after controlling the smoking habit. Ex-smokers who had stopped smoking for 10 years had a lower prevalence of COPD and respiratory symptoms than those who were still smokers (Liu et al., 2015). The results of this study (Table 4) showed that there were differences measurement of lung function based on difference in smoking duration (less than 10 years, 10 years to 20 years, and more than 20 years). However, in some respondents this difference did not occur, perhaps because of the influence of other factors such as age, exposure to harmful particles, and the development of lung function in childhood (Liu et al., 2015).

One study stated that there was significant evidence that smokers who reduce their consumption of cigarettes had a lower risk of lung cancer, cardiovascular disease, COPD, and all causes of mortality than those that do not reduce the amount of cigarette smoking. But the limit of smoking reduction which can reduce the risks of respiratory disease has not been determined (Lee et al., 2013). The use of cumulative cigarette consumption in the future can show a consistent relationship between pulmonary disease and smoker classification as non-smokers, ex-smokers and smokers which are differentiated based on the number of smoked cigarettes in a day. A research conducted by Hariri et al. (2016) found that pulmonary function values decreased in smokers and non-smokers. In addition, a significant correlation was found between the number of cigarettes smoked per day and the duration of smoking with a decrease in the value of FVC and FEV1. The results showed a decrease in lung function due to the number of cigarettes smoked per day (Table 5). Therefore, the number of cigarettes smoked per day can affect pulmonary function in accordance with above theory that the number of cigarettes smoked per day is associated with a decrease in 
the value of FEV1 (Lee et al., 2013).

The Brinkman index is used to see the degree of severity of smoking by using formula of cigarettes smoked a day multiplied by the length of smoking in the year. There is a significant relationship between the degree of smoking and the severity of COPD (Amelia et al., 2016; Shamara, Fachri, 2014). In the group of respiratory disorders (Table 4), the results of this study were in accordance with the theory that the severity of smoking has a significant relationship with the severity of COPD disease, in this case, based on the value of lung function. But in groups without respiratory disorders, it was not in accordance with the existing theory. This might occur due to lack of respondents, hence, data bias occurred. It could also be influenced by various other factors, such as genetics, disease history and nutritional intake. From the results of this study (Table 4), it could not be ascertained whether the duration of work could be used as a sign that the respondents were exposed to air pollution. Other data are needed in future research such as the distance between the house and the workplace, how long the distance that the driver travelled in work every day, the number of cars passing near the house, and it is also necessary to measure the number of dangerous particles at work or near the house (Schikowski et al., 2014).

When comparing the age group in group with respiratory disorders, respondents above age 40 years experienced decrease in lung function which was in accordance with previous theory. However, in group without respiratory disorders, when comparing respondents under 40 years of age to those above 40 years, there was no significant decline. There was a mismatch between the values of pulmonary function in the group without respiratory disorders and existing theory. The average age in group without respiratory disorders which were above 40 years was 50 years. At that age, lung function in respondents had decreased as in groups with respiratory disorders. The finding could be influenced by several factors such as smoking time, number of cigarettes smoked per day, history of disease and exposure to air pollution (Lowery et al., 2013)

A significant relationship was found between an increase in BMI and a decrease in lung volume / capacity of patients with COPD which could result in interpretation of measurements of lung function results (O'Donnell et al., 2014)the prevalence of both chronic obstructive pulmonary disease (COPD. The prevalence of COPD was reported to increase by $5 \%$ during 14 -year interim period and up to $38 \%$ in non-COPD subjects during the same period. Patients with COPD in the Netherlands have an obesity prevalence of $18 \%$, and highest BMI was obtained in patients with low spirometry results. Other studies have linked obesity with decreased pulmonary function. End-respiratory lung volume (EELV) and expiratory reserve volume (ERV) were decreased exponentially with increased BMI, residual volume was relatively stable or only slightly reduced, and the most important is the increased rest time related to increased BMI (Hanson et al., 2014). Other studies also found that obese individuals showed a decrease in lung volume and lung capacity when compared to those who were not obese. Reduction of total lung capacity and vital capacity, accompanied by a decrease in expiratory reserve volume after a representative finding among samples, shows the existence of restrictive respiratory symptoms associated with obesity. Obesity is a major risk factor for cardiovascular disease, several types of cancer, and type 2 diabetes mellitus. In addition, it is also known that central obesity is associated with various respiratory disorders including resistance to air flow, breathing patterns, gas exchange, respiratory mechanics and eventually will results in abnormalities in pulmonary function tests. One study concluded that an increase in body mass index must be considered to evaluate its effects on respiratory function. Body mass index is an independent variable that influences the prediction results on spirometry. Several foreign studies have been conducted which showed that BMI significantly affects all lung volumes and the greatest effect occurs in residual functional capacity and expiratory reserve volume (Melo et al., 2014).

In the group with respiratory disorders, most of the respondent (66.66\%) had 3 risk factors. This was the same as the group without respiratory disorders (84.61\%). However, respondent with 5 risk factors was only found 
Table 4. Frequency Distribution of Risk Factors of Respondents

\begin{tabular}{|c|c|c|c|c|c|}
\hline \multicolumn{2}{|l|}{ Risk Factors Owned } & \multicolumn{4}{|c|}{ Respondents (n:148) } \\
\hline & & \multicolumn{2}{|c|}{$\begin{array}{l}\text { Group with Respiratory } \\
\text { Disorders (n:135) }\end{array}$} & \multicolumn{2}{|c|}{$\begin{array}{l}\text { Group without Respiratory } \\
\text { Disorders (n:13) }\end{array}$} \\
\hline & & Frequency & Percentage (\%) & Frequency & Percentage (\%) \\
\hline \multicolumn{6}{|l|}{ Smoke } \\
\hline \multirow[t]{3}{*}{ Types of cigarettes } & kretek & 14 & 10.37 & 1 & 7.69 \\
\hline & white & 100 & 74.07 & 7 & 53.84 \\
\hline & anything & 21 & 15.55 & 5 & 38.46 \\
\hline \multirow[t]{3}{*}{ Smoking time } & $1-10$ years & 6 & 4.44 & 1 & 7.69 \\
\hline & $10-20$ years & 49 & 36.29 & 10 & 76.92 \\
\hline & $>20$ years & 80 & 59.25 & 2 & 15.38 \\
\hline \multirow{2}{*}{$\begin{array}{l}\text { Number of cigarettes } \\
\text { smoked a day }\end{array}$} & $<12$ cigarettes & 48 & 35.55 & 7 & 53.84 \\
\hline & $>12$ cigarettes & 87 & 64.44 & 4 & 30.76 \\
\hline \multirow[t]{3}{*}{ Brinkman index } & light & 10 & 7.40 & 1 & 7.69 \\
\hline & moderate & 70 & 51.85 & 1 & 7.69 \\
\hline & heavy & 55 & 37.07 & 11 & 84.61 \\
\hline \multicolumn{6}{|l|}{ Air pollution } \\
\hline \multirow{2}{*}{$\begin{array}{l}\text { Length of time as } \\
\text { pedicab driver }\end{array}$} & $5-10$ years & 2 & 1.48 & 1 & 7.69 \\
\hline & $>10$ years & 133 & 98.51 & 12 & 92.30 \\
\hline \multirow[t]{2}{*}{ Length of work in a day } & $<8$ hours a day & 11 & 8.14 & 0 & 0 \\
\hline & $>8$ hours a day & 124 & 91.85 & 13 & 100 \\
\hline \multicolumn{6}{|l|}{ Age } \\
\hline \multirow[t]{2}{*}{ Age (years) } & $<40$ & 10 & 7.40 & 2 & 15.38 \\
\hline & $>40$ (more risky) & 125 & 92.59 & 11 & 84.61 \\
\hline \multicolumn{6}{|l|}{ Obesity } \\
\hline \multirow[t]{3}{*}{ BMI $\left(\mathrm{kg} / \mathrm{m}^{2}\right)$} & obesity (>25) & 26 & 19.25 & 3 & 23.07 \\
\hline & overweight (23-24.99) & 19 & 14.07 & 1 & 7.9 \\
\hline & normal (18.5-22.99) & 81 & 60.0 & 8 & 61.53 \\
\hline \multicolumn{6}{|l|}{ History of the disease } \\
\hline \multirow{4}{*}{$\begin{array}{l}\text { History of chronic } \\
\text { diseases }\end{array}$} & diabetes & 4 & 2.96 & 0 & 0 \\
\hline & dyslipidemia & 3 & 2.22 & 0 & 0 \\
\hline & hyperuricemia & 3 & 2.22 & 0 & 0 \\
\hline & hypertension & 4 & 2.96 & 0 & 0 \\
\hline \multicolumn{6}{|c|}{ Total number of Risk Factors Owned } \\
\hline 1 & & 1 & 0.74 & 0 & 0 \\
\hline 2 & & 1 & 0.74 & 1 & 7.69 \\
\hline 3 & & 90 & 66.66 & 11 & 84.61 \\
\hline 4 & & 40 & 29.62 & 1 & 7.69 \\
\hline 5 & & 3 & 2.22 & 0 & 0 \\
\hline
\end{tabular}

in the group with pulmonary function disorder (2.22\%) (Table 4).

The initial symptoms associated with COPD (Table 5) were only found in group 1 with most common initial symptoms were shortness of breath (11 respondents or $8.14 \%$ ), chronic cough $(2.22 \%)$, wheezing (2.96\%), chest tightness $(0.74 \%)$, and limitation on physical activity $(2.22 \%)$. Based on initial symptoms of chronic cough (Table 5) in group with respiratory disorders, in term of last experienced cough, 2 respondents currently 
Table 5. Profile of Initial Symptoms related to COPD Experienced by Respondents

\begin{tabular}{|c|c|c|c|c|c|}
\hline & & \multicolumn{2}{|c|}{$\begin{array}{l}\text { Group with Respiratory } \\
\text { Disorders (n:135) }\end{array}$} & \multicolumn{2}{|c|}{$\begin{array}{l}\text { Group without Respiratory } \\
\text { Disorders (n:13) }\end{array}$} \\
\hline & & Frequency & Percentage $(\%)^{*}$ & Frequency & Percentage $(\%)^{\star}$ \\
\hline Chronic cough (n:3) & & 3 & 2.22 & 0 & 0 \\
\hline \multirow[t]{3}{*}{ Last experienced cough } & now & 2 & 1.48 & 0 & 0 \\
\hline & previous & 1 & 0.74 & 0 & 0 \\
\hline & never & 0 & 0 & 0 & 0 \\
\hline \multirow{2}{*}{$\begin{array}{l}\text { Type of cough that was } \\
\text { experienced }\end{array}$} & productive cough & 0 & 0 & 0 & 0 \\
\hline & dry cough & 3 & 2.22 & 0 & 0 \\
\hline \multirow[t]{2}{*}{ Duration of cough } & last 3 months & 2 & 1.48 & 0 & 0 \\
\hline & $<3$ months & 1 & 0.74 & 0 & 0 \\
\hline \multirow[t]{2}{*}{ Frequency of cough } & every day & 0 & 0 & 0 & 0 \\
\hline & sometimes & 3 & 2.22 & 0 & 0 \\
\hline \multirow[t]{2}{*}{ Cause of cough } & dust & 2 & 1.48 & & 0 \\
\hline & tiredness & 1 & 0.74 & 0 & 0 \\
\hline Shortness of breath (n: 11) & & 11 & 8.14 & 0 & 0 \\
\hline \multirow[t]{2}{*}{ History of symptom } & yes, now & 8 & 5.92 & 0 & 0 \\
\hline & yes, once & 3 & 2.22 & 0 & 0 \\
\hline \multirow{2}{*}{$\begin{array}{l}\text { Time when the symptom } \\
\text { appears }\end{array}$} & at work & 10 & 7.40 & 0 & 0 \\
\hline & at rest & 1 & 0.74 & 0 & 0 \\
\hline \multirow[t]{2}{*}{ Cause of the symptom } & tiredness & 9 & 6.66 & 0 & 0 \\
\hline & dust & 2 & 1.48 & 0 & 0 \\
\hline Wheezing (n: 4) & & 4 & 2.96 & 0 & 0 \\
\hline \multirow[t]{2}{*}{ History of symptom } & yes, now & 1 & 2.22 & 0 & 0 \\
\hline & yes, once & 3 & 0.74 & 0 & 0 \\
\hline \multirow[t]{2}{*}{ History of the symptom } & now & 1 & 0.74 & 0 & 0 \\
\hline & before & 3 & 2.22 & & 0 \\
\hline \multirow[t]{2}{*}{ When the symptom appears } & sleep & 1 & 0.74 & 0 & 0 \\
\hline & work & 3 & 2.22 & 0 & 0 \\
\hline \multicolumn{2}{|l|}{ Chest tightness (n: 3 ) } & 3 & 0.74 & 0 & 0 \\
\hline \multirow[t]{2}{*}{ History of symptoms } & yes, until now & 1 & 0.74 & 0 & 0 \\
\hline & yes, first & 2 & 1.48 & 0 & 0 \\
\hline \multirow[t]{2}{*}{ Causes of symptoms } & tiredness & 3 & 2.22 & 0 & 0 \\
\hline & dust & 0 & 0 & 0 & 0 \\
\hline \multicolumn{2}{|l|}{ Limitation of physical activity (n: 3 ) } & 3 & 2.22 & 0 & 0 \\
\hline \multirow{2}{*}{$\begin{array}{l}\text { Previous history of limited } \\
\text { activity }\end{array}$} & yes, now & 2 & 1.48 & 0 & 0 \\
\hline & yes, once & 1 & 0.74 & 0 & 0 \\
\hline \multicolumn{2}{|c|}{ Total number of early symptoms related to COPD } & 3 & 2.22 & 0 & 0 \\
\hline \multicolumn{2}{|l|}{0} & 114 & 84.44 & 0 & 0 \\
\hline \multicolumn{2}{|l|}{1} & 8 & 5.92 & 0 & 0 \\
\hline \multicolumn{2}{|l|}{2} & 5 & 3.70 & 0 & 0 \\
\hline \multicolumn{2}{|l|}{3} & 1 & 0.7 & 0 & 0 \\
\hline \multicolumn{2}{|l|}{4} & 0 & 0 & 0 & 0 \\
\hline
\end{tabular}

${ }^{*}$ percentage of total group 
experienced cough and 1 respondents previously experienced one; in term of the type of cough experienced, all of them experienced dry cough; in term of duration of cough, 2 respondents had cough for the last 3 months and 1 respondent had cough for less than 3 months; in term of the frequency of cough, all of them only experienced cough sometimes; and in term of cause of cough, 2 respondents said that the cause was dust and 1 respondent said that the cause was tiredness.

Productive cough occurred almost every day for at least 3 months a year in 2 consecutive years. Chronic cough is associated with worsening obstruction of airflow and progressive decrease in pulmonary function (Song et al., 2017)the definitions vary greatly among epidemiological studies, and none have been validated for clinical relevance. We aimed to examine previous epidemiological definitions in detail and explore the operational characteristics. A systematic review was conducted for epidemiological surveys that reported the prevalence of chronic cough in general adult populations during the years 1980 to 2013. A literature search was performed on Pubmed and Embase without language restriction. Epidemiological definitions for chronic cough were classified according to their components, such as cutoff duration. Meta-analyses were performed for the maleto-female ratio of chronic cough prevalence to explore operational characteristics of epidemiological definitions. A total of 70 studies were included in the systematic review. The most common epidemiological definition was identified as 'cough $\geq 3$ months' duration without specification of phlegm $\quad(n=50$. Pathophysiologically, chronic cough can be regarded as an initial symptom of COPD that occurs due to mucus hypersecretion. However, not all COPD patients experience this symptom because it depends on the number of goblet cells and enlarged submucosal glands in response to chronic airway irritation by cigarette smoke or other harmful particles (Kim, Criner, 2013)

Among 148 respondents, only 3 respondents experienced symptom of chronic cough with pulmonary function values of $25.22 \%, 44.58 \%$, and $46.43 \%$, respectively. This finding showed that early symptom of chronic cough could affect lung function. The low number of respondents who experienced the symptom could be caused by low levels of education, lack of awareness about the health of the respondents and the lack of openness of respondents at the time of the interview.

GOLD (2019) states that tightness is a condition where an imbalance of gas exchange causes hypoxemia and hypercapnea. The results of this study showed that the initial symptom of shortness of breath only occurred in 11 respondents of group with respiratory disorders. This finding showed that the initial symptom of shortness of breath could be used as an initial diagnosis of respiratory disease if it was accompanied with a decrease in lung function of the respondents.

Wheezing is a high-pitched whistling sound that occurs when a person inhales and exhales. Wheezing can occur because the air moved through small and narrow airways due to inflammation. The air which is flowing through the narrow channel becomes turbulent and causes vibration of the airway wall which produce wheezing sound (Gidaris, Cunningham, 2013). The results of this study showed that only 4 respondents in group with respiratory disorders who experienced symptom of wheezing. This showed a decrease in lung function in respondents who experienced early symptoms of wheezing. A study stated that low lung function was more likely to occur in respondents who experienced recurrent wheezing symptoms (Soh et al., 2017)

Chest tightness is a feeling which resembles when the chest is pressed by a heavy object or tied tightly so that it makes difficult to breathe (Burki, Lee, 2010). The results of this study found only 1 respondent who experienced initial symptom of chest tightness with pulmonary function value of 35.36 . The respondent experienced these symptom when he was finished taking passengers.

In people who experience COPD, their physical activity is reduced. This is associated with a high risk of hospital admission and increased risks of mortality and developing comorbidity. Increasing one's activities can make the people to perform various productive and positive things that benefit their lives. A study stated that physical activity was reduced 
in patients with chronic obstructive pulmonary disease (Bossenbroek et al., 2011). The results of this study showed that there were 3 respondents who experienced initial symptoms of limitation of physical activity. This showed a decrease in lung function in respondents who experienced symptoms of limitation of physical activity.

In the group without respiratory disorders no one had early symptoms related to COPD. However, in the group with respiratory disorders, most of the respondents also did not have early symptoms related to COPD (84.44\%) and the highest number of symptoms they had was 1 symptom (5.92\%) (Table 5).

There were some limitations of this study. During preparation of lung function tests, the respondent should not smoke 1 hour before the test, however, in practice, many respondents filled their spare time while waiting for passengers by smoking which could affect the measurement of lung function. Moreover, in this study, the data collection were usually conducted to pedicab drivers who were waiting for passengers. During interview, other pedicab drivers could hear and see the respondent who was being interviewed. This could affect the results of interviews because there were feelings of shame or fear when other pedicab drivers know about their health or circumstances. Finally, the measurement of height and weight were not in accordance with the standard due to the limitations of the tools used.

\section{Conclusion}

In this study it was not possible to compare the group with respiratory disorders and group without respiratory disorders, because the number of respondents in each groups was very different. Most pedicab drivers (91.21\%) who were respondents had lung function disorders. In both groups, most of the respondents had 3 risk factor. Respondents with 5 risk factors $(2.22 \%)$ were only found in group with respiratory. Based on the initial symptoms associated with COPD, all of the respondents in the group without respiratory problems did not have any symptoms while most of the respondents (84.44\%) in group with respiratory disorders also did not have any symptoms related to COPD. Most of respondents who had symptom in group with respiratory disorders only experienced 1 symptom (5.92\%).

\section{References}

Amelia, R., Nasrul, E., Basyar, M., 2016. Hubungan Derajat Merokok Berdasarkan Indeks Brinkman dengan Kadar Hemoglobin. Jurnal Kesehatan Andalas, 5(3), pp.619-24.

Alamsyah, R., Natamihaja, L., Handayani, R., 2012. Hubungan Kebiasaan Merokok dengan Status Periodontal Tukang Becak di Sekitar Kampus USU Medan. Dentika Dental Journal, 17(2), pp.128-33.

RISKESDAS., 2013. Riset Kesehatan Dasar (RISKESDAS) 2013. Badan Penelitian dan Pengembangan Kesehatan, Jakarta.

Boediningsih, W., 2011. Dampak Kepadatan Lalu Lintas Terhadap Polusi Udara Kota Surabaya. Jurnal Fakultas Hukum, 20(20), pp.119-38.

Bossenbroek, L., Greef, M.H., Wempe, J.B., Krijnen, W.P., Hacken, T.N.H., 2011. Daily physical activity in patients with chronic obstructive pulmonary disease: a systematic review. COPD, 8(4), pp.306-19.

Burki, N.K., Lee, L.Y., 2010. Mechanisms of dyspnea. Chest, 138(5), pp.1196-201.

Farooque, I., Jayachandra, S., 2014. Pulmonary Function Tests in Nonsmoking Auto Rickshaw Drivers. Al Amin Journal of Medical Science, 7(3), pp.240-3.

Fletcher, M.J., Upton, J., Taylor-Fishwick, J., Buist, S.A., Jenkins, C., Hutton, J., Barnes, N., Molen, V.D.T., Walsh, J.W., Jones, P., Walker, S., 2011. COPD uncovered: an international survey on the impact of chronic obstructive pulmonary disease [COPD] on a working age population. BMC Public Health, 11(1), pp.612.

Forum of International Respiratory Societies., 2017. The Global Impact of Respiratory Disease - Second Edition. European Respiratory Society, Sheffield.

Gidaris, D., Cunningham, S., 2013. Wheezing defined. Front Biosci (Elite Ed), E5(3), pp.1074-81.

GOLD (Global Initiated For Chronic Lung Disease)., 2018. Global Strategy for the Diagnosis, Management, and Prevention of Chronic Obstructive Pulmonary Disease (2018 Report). Global Initiative for Chronic Obstructive Disease, Inc, USA.

Hanson, C., Rutten, E.P., Wouters, E.F., Rennard, S., 2014. Influence of diet and obesity on COPD development and outcomes. Int J Chron Obstruct Pulmon Dis, 9, pp.723-733.

Hajat, A., Hsia, C., O’Neill, M.S., 2015. Socioeconomic Disparities and Air Pollution Exposure: A Global Review. Curr Environ Health Rep, 2(4), pp.440-450. 
Hariri, M.A., Zibara, K., Farhat, W., Hashem, Y., Soudani, N., Ibrahim, F.A., Hamade, E., Zeidan, A., Husari, A., Kobeissy, F., 2016. Cigarette Smoking-Induced Cardiac Hypertrophy, Vascular Inflammation and Injury Are Attenuated by Antioxidant Supplementation in an Animal Model. Front Pharmacol, 7, pp.397.

Harahap, F., Aryastuti, E., 2012. Uji Fungsi Paru. CDK, 192, pp. 305-7.

Hamer, D.H., Sempértegui, F., Estrella, B., Tucker, K.L., Rodríguez, A., Egas, J., Dallal, G.E., Selhub, J., Griffiths, J.K., Meydani, S.N., 2009. Micronutrient deficiencies are associated with impaired immune response and higher burden of respiratory infections in elderly Ecuadorians. J Nutr, 139(1), pp.113-9.

Hu, G., Zhong, N., Ran, P., 2015. Air Pollution and COPD in China. Journal of Thoacic Disease, 7(1), pp.59-66.

Hurt, R.D., Ebbert, J.O., Achadi, A., Croghan, I.T., 2012. Roadmap to a Tobacco Epidemic: Transnational Tobacco Companies Invade Indonesia. Tob Control, 21(3), pp.306-312.

Indari, 2016. Kebijakan Transportasi Becak di Surabaya Tahun 1970-1980. AVATARA, 4(1), pp.75-88.

Jiang, X.Q., Mei, X.D., Feng, D., 2016. Air Pollution and Chronic Airway Diseases: What Should People Know and Do?. Journal of Thoracic Disease, 8(1), pp.E31-40.

Jitnarin, N., Kosulwat, V., Rojroongwasinkul, N., Boonpraderm, A., Haddock, C.K., Poston, W.S.C., 2014. The Relationship Between Smoking, Body Weight, Body Mass Index, and Dietary Intake Among Thai Adults: Results of the National Thai Food Consumption Survey. Asia Pac J Public Health, 26(5), pp.481-493.

Kelly, F.J., 2014. Influence of Air Pollution on Respiratory Disease. European Medical Journal, 2, pp.96-103.

Kim, V., Criner, G.J., 2013. Chronic bronchitis and chronic obstructive pulmonary disease. Am J Respir Crit Care Med, 187(3), pp.228-37.

Kirkorowicz, J.M., Sapukotana, P., Silva, P.V.D., Noda, M., Oliveira, J.S., 2013. Work-Related Stress and Substance Use as Risk Factors for Chronic Disease Among Three-Wheel Drivers in Galle, Sri Lanka: A Qualitative Study. International Journal of Occupational Safety and Health, 3(2), pp.21-24.

Ko, F.W., Hui, D.S., 2012. Air Pollution and Chronic Obstructive Pulmonary Disease. Respirology, 17(3), pp.395-401.
Lee, N., Lui, G.C., Wong, K.T., Li, T.C., Tse, E.C., Chan, J.Y., Yu, J., Wong, S.S., Choi, K.W., Wong, R.Y., Ngai, K.L., Hui, D.S., Chan, P.K., 2013. High morbidity and mortality in adults hospitalized for respiratory syncytial virus infections. Clin Infect Dis, 57(8), pp.1069-77.

Li, J., Sun, S., Tang, R., Qiu, H., Huang, Q., Mason, T.G., Tian, L., 2016. Major Air Pollutants and Risk of COPD Exacerbations: A Systematic Review and Meta-Analysis. International Journal of COPD, 11, pp.3079-91.

Lowery, E.M., Brubaker, A.L., Kuhlmann, E., Kovacs, E.J., 2013. The aging lung. Clin Interv Aging, 8, pp.1489-96.

Liu, Y., Pleasants, R.A., Croft, J.B., Wheaton, A.G., Heidari, K., Malarcher, A.M., Ohar, J.A., Kraf, M., Mannino, D.M., Strange, C., 2015. Smoking duration, respiratory symptoms, and COPD in adults aged $\geq 45$ years with a smoking history. Int JChron Obstruct Pulmon Dis, 10, pp.1409-16.

Mangatta, B.H., 2016. Strategi Adaptasi Tukang Becak Dalam Kehidupan Sosial Ekonomi (Studi Kasus Tukang Becak Di Kelurahan Bontobiraeng Kecamatan Mamajang Kota Makassar). Jurnal Holistik, IX(18), pp.1-22.

Melo, L.C., Silva, M.A., Calles, A.C., 2014. Obesity and lung function: a systematic review. Einstein (Sao Paulo), 12(1), pp.120125.

Malson, J.L., Lee, E.M., Murty, R., Moolchan, E.T., Pickworth, W.B., 2003. Clove cigarette smoking: biochemical, physiological, and subjective effects. Pharmacol Biochem Behav, 74(3), pp.739-45.

Nuttall, F.Q., 2015. Body Mass Index: Obesity, BMI, and Health: A Critical Review. Nutrition Research, 30(3), pp.117-128.

O’Donnell, D.E., Laveneziana, P., Webb, K., Neder, J.A., 2014. Chronic obstructive pulmonary disease: clinical integrative physiology. Clin Chest Med, 35(1), pp.51-69.

Perhimpunan Dokter Paru Indonesia (PDPI)., 2011. Penyakit Paru Obstruktif Kronik (PPOK). Pedoman Diagnosis \& Penatalaksanaan di Indonesia, Jakarta.

Peng, Y., Li, X., Cai, S., Chen, Y., Dai, W., Liu, W., Zhou, Z., Duan, J., Chen, P., 2018. Prevalence and characteristics of COPD among pneumoconiosis patients at an occupational disease prevention institute: a cross-sectional study. BMC Pulmonary Medicine, 18, pp.22.

Schikowski, T., Adam, M., Marcon, A., Cai, Y., Vierkötter, A., Carsin, A.E., Jacquemin, B., Al Kanani, Z., Beelen, R., Birk, M., Bridevaux, P.O., Brunekeef, B., Burney, 
P., Cirach, M., Cyrys, J., Hoogh, K.D., Marco, R.D., Nazelle, A.D., Declercq, C., Forsberg, B., Hardy, R., Heinrich, J., Hoek, G., Jarvis, D., Keidel, d., Kuh, D., Kuhlbusch, T., Migliore, E., Mosler, G., Nieuwenhuijsen, M.J., Phuleria, H., Rochat., T., Schindler, C., Villani., S., Tsai, M.Y., Zemp, E., Hansell, A., Kauffmann, F., Sunyer, J., Probst-Hensch, N., Kramer, U., Kunzli, N., 2014. Association of ambient air pollution with the prevalence and incidence of COPD. Eur Respir J, 44(3), pp.614-26.

Shamara, F., Fachri, M., 2014. Karakteristik Pasien Penyakit Paru Obstruktif Kronik Stabil Dikaitkan dengan Kebiasaan Merokok Berdasarkan Nilai Indeks Brinkman di Rumah Sakit Islam Jakarta (RSIJ) Sukapura. J Indon Med Assoc, 64(12), pp.564-569.

Silalahio, V., Aritonang, E., Ashar, T., 2016. Potensi Pendidikan Gizi Dalam Meningkatkan Asupan Gizi Pada Remaja Putri Yang Anemi Di Kota Medan. Jurnal Kesehatan Masyarakat, 11(2), pp.96-102.

Song, W.J., Chang, Y.S., Faruqi, S., Kang, M.K., Kim, J.Y., Kang, M.G., Kim, S., Jo, E.J., Lee, S/E/. Kim, M.H., Plevkova, J., Park, H.W., Cho, S.H., Morice., A.H., 2016. Defining Chronic Cough: A Systematic Review of the Epidemiological Literature. Allergy Asthma Immunol Res, 8(2), pp.146-155.

Soh, J.E., Kim, K.M., Kwon, J.W., Kim, H.Y., Seo, J.H., Kim, H.B., Lee, S.Y., Jang, G.C., Song, D.J.,
Kim ,W.K., Jung, Y.H., Hong, S.J., Shim, J.Y., 2017. Recurrent wheeze and its relationship with lung function and airway inflammation in preschool children: a cross-sectional study in South Korea. BMJ Open, 7, pp.e018010.

Union of Concerned Scientists., 2018. Clean Vehicles [online]. Available at: https://www.ucsusa. org/contact-us-full (Accessed: 9 March 2019).

Uyainah, A.Z.N., Amin, Z., Thufeilsyah, F., 2014. Spirometri. Ina J Chest Crit and Emerg Med, 1(1), pp.35-38.

Walker, S.L., Saltman, D.L., Colucci, R., Martin, L., 2010. Awareness of Risk Factors among Persons at Risk for Lung Cancer, Chronic Obstructive Pulmonary Disease and Sleep Apnea: A Canadian Population-Based Study. Canadian Respiratory Journal, 17(6), pp.287294.

Wang, P., Abdin, E., Sambasivam, R., Chong, S.A., Vaingankar, J.A., Subramaniam, M., 2016. Smoking and Socio-demographic correlates of BMI. BMC Public Health, 16, pp.500.

Yawn, B.P., 2013. Early Identification of Exacerbations in Patients with Chronic Obstructive Pulmonary Disease. Journal of Primary Care \& Community Health, 4(1), pp.75-80.

Zhang, K., Batterman, S., 2013. Air Pollution and Health Risks Due to Vehicle Traffic. Science of the Total Environment, 0, pp.307-316. 